Al-Fikra: Jurnal Ilmiah Keislaman, Vol. 5, No. 1, Januari-Juni 2006

\title{
AGAMA DAN SOLIDARITAS SOSIAL: Pandangan Islam Terhadap Pemikiran Sosiologi Emile Durkheim
}

\author{
Kamiruddin \\ Fakultas Syari'ah dan Ilmu Hukum UIN Suska Riau, Pekanbaru
}

\begin{abstract}
Religion and Social Solidarity : How Islam views the social ideology of Emile Durkheim: This article discusses Emile Durkheim's idea on the relationship between religion and social solidarity and then it is compared with how Islam views it. This study is merely based on social approach, not to discover which religion is correct or wrong (collective), but only to describes the impacts of religious teaching on social life empirically. This study is of great importance especially to understand Durkheim's idea on the above issue which hopefully clarifies the relationship between religion and social solidarity. From Durkheim's view it is obvious that religion is a projection of the experience of the community. Sanctity and community are united that have something in common and religion is a tool to symbolically express life totally. According to Durkheim, religion and the community are inseparable. According to him, the stronger the social solidarity of a community, the deeper their religious feeling about sacred matters will be, which goes together with the collective manifestation. In fact, Islam can increase the solidarity of Muslims because they do religious ritual activities (liturgis) together (jamaah) and they interact one another which later results in a strong solidarity among them.
\end{abstract}

Keywords: Social Solidarity, religion, sosiology.

\section{Pendahuluan}

Bentuk umum proses sosial adalah interaksi sosial, oleh karena interaksi sosial syarat utama terjadinya aktivitas-aktivitas sosial. Bentuk lain dari proses sosial hanya merupakan bentuk-bentuk khusus dari interaksi sosial. Interaksi sosial merupakan hubungan- hubungan sosial yang dinamis yang menyangkut hubungan antara orang-orang perorangan, antara kelompok-kelompok manusia, maupun antara perorangan dengan kelompok manusia. Apabila dua orang bertemu, interaksi sosial dimualai pada saat itu. Mereka saling menegur, berjabat tangan dan atau saling berbicara. Aktivitas-aktivitas semacam itu merupakan bentuk-bentuk interaksi sosial.

Interaksi sosial antara kelompok-kelompok manusia terjadi pula dalam masyarakat. Interaksi sosial tidak mungkin terjadi apabila manusia mengadakan hubungan yang langsung dengan sesuatu yang sama sekali tidak berpengaruh terhadap sistem syarafnya, sebagai akibat hubungan termaksud.

Berlangsungnya suatu proses interaksi didasarkan pada berbagai faktor, antara lain, faktor imitasi, sugesti, identifikasi dan simpati. Faktor-faktor tersebut dapat bergerak sendiri-sendiri secara terpisah maupun dalam keadaan tergabung. Apabila masing-masing ditinjau secara mendalam, maka faktor 
imitasi misalnya mempunyai peranan yang sangat penting dalam proses interaksi sosial. Segi positifnya adalah bahwa imitasi dapat mendorong seseorang untuk mematuhi kaidah-kaidah dan nilai-nilai yang berlaku. Namun demikian, imitasi mungkin pula mengakibatkan terjadinya hal-hal yang negatif di mana misalnya, yang ditiru adalah tindakan-tindakan yang menyimpang. Selain itu, imitisi juga dapat melemahkan atau bahkan mematikan pengembangan daya kreasi seseorang.

Identifikasi sebenarnya merupakan kecenderungan atau keinginankeinginan dalam diri seseorang untuk menjadi sama dengan pihak lain. Identifikasi sifatnya lebih mendalam daripada imitasi, oleh karena kepribadian seseorang dapat terbentuk atas dasar proses ini. Proses identifikasi dapat berlangsung dengan sendirinya (secara tidak sadar), maupun dengan disengaja oleh karena seringkali seseorang memerlukan tipe-tipe ideal tertentu di dalam proses kehidupannya. Walaupun dapat berlangsung dengan sendirinya, proses identifikasi berlangsung dalam suatu keadaan di mana seseorang yang beridentifikasi benar-benar mengenal fihak lain (yang menjadi idealnya), sehingga pandangan, sikap hidup maupun kaidah-kaidah yang berlaku pada fihak lain tadi dapat melembaga dan bahkan menjiwainya.

Proses simpati sebenarnya merupakan suatu proses di mana seseorang merasa tertarik pada fihak lain. Perasaan memegang peranan yang sangat penting, walaupun dorongan utama pada simpati adalah keinginan untuk memahami fihak lain dan untuk bekerja sama dengannya. Inilah perbedaan utamanya dengan identifikasi yang didorong oleh keinginan untuk belajar dari fihak lain yang dianggap kedudukannya lebih tinggi dan harus dihormati karena mempunyai kelebihan-kelebihan tertentu yang patut dijadikan contoh.

Hal tersebut di atas merupakan faktor-faktor minimal yang menjadi dasar bagi berlangsungnya proses interaksi sosial, walaupun dalam kenyataannya proses tadi memang sangat kompleks, sehingga kadang-kadang sulit mengadakan pembedaan tegas antara faktor-faktor tersebut.

Masyarakat adalah gabungan dari kelompok individu yang terbentuk berdasarkan tatanan sosial tertentu. ${ }^{1}$ Dalam kepustakaan ilmu-ilmu sosial dikenal tiga bentuk masyarakat, yaitu: 1) masyarakat homogen; 2) masyarakat majemuk; 3) masyarakat heterogen.

Masyarakat homogen ditandai oleh adanya ciri-ciri yang anggotanya tergolong dalam satu asal atau suku bangsa dengan satu kebudayaan yang digunakan sebagai pedoman hidup sehar-hari. Masyarakat homogen dapat ditemukan dalam bentuk satuan-satuan masyarakat berskala kecil tetapi ada juga yang terwujud dalam masyarakat berskala besar. Sedangkan masyarakat majemuk terdiri atas sejumlah suku bangsa yang merupakan bagian dari bangsa itu. Selanjutnya masyarakat heterogen memiliki ciri-ciri; 1.Pranata-pranata primer yang bersumber dari kebudayaan suku bangsa telah diseragamkan oleh pemerintah nasional; 2.Kekuatan-kekuatan politik suku bangsa telah

${ }^{1}$ Koentjaraningrat, Ilmu Antropologi, (Jakarta: PT.Rineka Cipta, 1990), hlm. 144 
dilemahkan oleh sistem nasional melalui pengorganisasian yang berdasarkan pada solidaritas; 3. Memiliki pranata alternatif yang berfungsi sebagai upaya untuk mengakomodasi perbedaan dan keragaman. ${ }^{2}$

Terlepas dari penggolongan masyarakat tersebut, pada dasarnya masyarakat terbentuk dari adanya solidaritas dan konsesus. Solidaritas merupakan suatu proses sosial, menjadi dasar terbentuknya kesetuan dalam masyarakat, sedangkan konsesus merupakan persetujuan bersama terhadap nilai-nilai dan norma-norma yang memberikan arah dan makna bagi kehidupan kelompok. Kedua aspek ini merupakan pengikat dalam kehidupan masyarakat. Apabila kedua unsur tersebut hilang dari suatu masyarakat, maka akan terjadi disorganisasi sosial serta bentuk sosial dan kultur sosial yang telah mapan akan ambruk.

Jika solidaritas dan konsesus dari suatu masyarakat dianggap sebagai unsur budaya yang digunakan sebagai pedoman hidup sehari-hari bersumber dari ajaran suatu agama, maka fungsi agama adalah sebagai motivasi, rasa, dan etos masyarakat. Dalam konteks ini, maka agama memberi pengaruh dalam menyatukan masyarakat. Sebaliknya agama juga dapat menjadi pemecah, jika solidaritas dan konsesus melemah dan mengendur. Kondisi seperti ini biasanya terlihat dalam masyarakat yang majemuk dan heterogen. Karena sikap fanatisme kelompok tertentu dalam masyarakat heterogen, akan memberi pengaruh dalam menjaga solidaritas dan konsesus bersama.

Tulisan ini bermaksud menjelaskan tentang bagaimana hubungan agama dengan solidaritas sosial itu dalam kerangka pemikiran Emile Durkheim. Emile Durkheim adalah seorang sosiolog besar, berkebangsaan Prancis, yang hidup antara tahun 1858 sampai tahun 1917. Karya beliau yang terkenal adalah, 1. The Social Division Of Labor (1819), 2. The Rules Of Sociological Method (1895), 3.The Elementary Form Of Religious Life

Tulisan ini bukan diarahkan kepada bagaimana cara seseorang beragama, benar salah suatu agama, melainkan diarahkan kepada kehidupan agama secara kolektif terutama dipusatkan kepada fungsi agama dalam mengembangkan atau menghambat kelangsungan hidup dan pemeliharaan kelompok-kelompok masyarakat. Perhatiannya juga ditujukan pada agama sebagai salah satu aspek dari tingkah laku kelompok dan kepada peranan yang dimainkannya selama berabad-abad hingga sekarang

\section{Solidaritas Sosial}

Istilah solidaritas terjemahan dari kata Inggris, solidarity, ${ }^{3}$ yaitu sifat satu rasa, merasa senasip sepenanggungan, setia kawan, ${ }^{4}$ integrasi sosial atau

\footnotetext{
2 Parsudi Suparlan, Orang Sakai Di Riau, Masyarakat Terasing Dalam Masyarakat Indonesia, (Jakarta: Yayasan Obor Indonesia, 1995), hlm. 12

${ }^{3}$ Lionel Kernermen, Password, (Bekasi Timur; PT.Kesaint blanc Indah Corp, 1999), hlm.483
} 
hubungan erat. ${ }^{5}$ Istilah ini digunakan oleh para sosiolog untuk menunjukkan hubungan atau interaksi antar manusia dalam komunitas sosial. Solidaritas juga dapat diartikan "rasa berkelompok/group feeling"," yaitu sekumpulan orangorang yang mempunyai rasa persatuan. Secara umum istilah ini pertama kali digunakan oleh Emile Durkheim, untuk menunjukkan bentuk-bentuk ikatan sosial. $^{7}$

Emile Durkheim membagi dua bentuk solidaritas, yaitu solidaritas mekanis (mechanical solidarity) dan solidaritas organis (organic solidarity). Perbedaan keduanya bersifat evolusionistis, dalam arti bahwa yang kedua adalah perkembangan dari yang pertama. Corak yang pertama adalah solidaritas mekanis, yaitu solidaritas yang didukung oleh persamaan dari individu-individu. Dengan kata lain, solidaritas mekanis terjadi karena diferensiasi atau perbedaan antara individu-individu masih sangat terbatas.

Solidaritas mekanis biasanya terdapat dalam masyarakat yang masih sangat sederhana, bersahaja "primitip" atau bisa pula disebut, meskipun tidak identik satu sama lain, "segmental", yaitu corak kelompok sosial dimana individu saling terikat secara utuh. Corak masyarakat yang segmental ini ditandai oleh "solidaritas kesamaan", yang mekanis. Masyarakat "segmental" juga relatif terisolasi satu sama lain dan bersifat mandiri. Setiap anggota masyarakat merasa memiliki, merasa terikat antara satu dengan yang lainnya, kepercayaan dan perasaan yang sama (kesadaran kolektif), gangguan terhadap satu anggota merupakan gangguan bagi semua anggota masyarakat, pelanggaran terhadap suatu norma merupakan ancaman bersama. Makanya menurut Durkheim pada masyarakat seperti demikian hukum yang berkembang adalah hukum yang bersifat represif, dimana sanksi yang diberikan bagi pelanggar hukum mendatangkan penderitaan, menjerahkan atau bahkan merampas kemerdekaan dan kenikmatan hidup pelakunya. Hal ini disebabkan karena pelanggaran dan kejahatan dianggap sebagai tindakan yang mencemarkan keyakinan bersama.

Berbeda dengan corak yang mekanis ini, maka solidaritas yang kedua yang disebut Durkheim solidaritas organis. Ini biasanya terdapat pada masyarakat yang sudah maju, perkotaan, dimana masyarakatnya sangat heterogen. Seseorang berhubungan dengan orang lain hanyalah karena ada ketergantungan/kepentingan dengan orang tersebut. Jika kepentingannya sudah selesai maka hubungan merekapun berakhir pula. Solidaritas organis terwujud karena telah berkembangnya diferensiasi ataupun spesialisasi. Masing-masing orang mempunyai profesi atau keahlian yang berbeda-beda

${ }^{4}$ Peter Salim, Yeni Salim, Kamus Bahasa Indonesia, (Jakarta; Modern English Press, 1991),hlm.237

${ }^{5}$ Soerjono Soekanto, Kamus Sosiologi, (Jakarta; PT.Raja Grafindo Persada, 1985), hlm. 472

6 Bryan S.Turner, Sosiologi Islam, Suatu Telaah analitis Atas Tesa Sosiologi Weber, alih bahasa, G.A.Ticoalu, (Jakarta: PT. Raja Grafindo Persada, 1994), hlm.195

7 Taufik Abdullah dan A.C.Vander Leeden (Penyunting), Durkheim dan Pengantar Sosiologi Moralitas, (Jakarta: Yayasan Obor indonesia, 1986), hlm.13 
sehingga terjadi pembagian kerja yang sangat kompleks. Dengan meningkatnya urbanisasi dan meluasnya pembagian kerja, solidaritas mekanis mulai luntur dan perlahan-lahan digantikan oleh prinsip intergrasi organis yang baru. Perkembangan kelas-kelas sosial dan spesialisasi kelompokkelompok profesional menyebabkan melemahnya nilai-nilai bersama dan ritual kolektif. Meskipun kesadaran kolektif tetap ada dalam societes superieures, namun dia menjadi semakin lemah, semakin abstrak dan tidak lagi berwibawa. Mobilitas kerja, urbanisasi dan diferensiasi sosial telah mencabut akar-akar tradisi dan menggerogoti kekuatan sentimen bersama, rasa simpati antara anggota masyarakat. Hukum yang berkembang dalam masyarakat seperti ini biasanya hukum yang bersifat restitutif, dimana sanksi yang diberikan kepada pelanggar hukum hanyalah bersifat mengembalikan keadaan semula, tidak berupa hukuman yang bisa merampas kemerdekaaan atau merusak diri pelaku.

Keutuhan sosial bukanlah sesuatu yang terjadi begitu saja, melainkan terjadi secara sadar atas dasar konsensus masyarakat. Disintegrasi dari solidaritas mekanis sebagai akibat perubahan sosial adalah sebab langsung dari timbulnya solidaritas organis itu. Makin modern dan heterogen suatu masyarakat maka makin hilanglah corak solidaritas yang mekanis dan semakin menonjolah sifat organisnya. Atau dengan kata lain, makin modern suatu masyarakat, maka makin jelaslah diferensiasi sosialnya. Dengan demikian, maka rasionalitas makin diperlukan demi tercapainya konsensus.

Karena masyarakat modern telah mengalami diferensiasi/spesialisasi, maka solidaritasnya bersifat kontraktual, perjanjian. Namun demikian Durkheim juga beranggapan bahwa dalam tingkat tertentu dari masyarakat organis, yang telah mengalami pembagian kerja itu, kadang-kadang masih bisa terdapat struktur yang bersifat segmental.

Kedua corak solidaritas itu tergantung pula pada kesadaran kolektif (conscience collective). Tanpa ini, apapun corak organisasi sosialnya, masyarakat dikutuk karena mengalami kemunduran dan kebangrutan. Masalah yang terberat, tentu saja bisa ditemukan ketika masyarakat sedang mengalami proses peralihan, dari mekanis ke organis. Di saat itu masyarakat kehilangan pedoman dan pegangan hidup. Inilah yang disebut Durkheim, anomie yaitu suasana tanpa norma. ${ }^{8}$ Dalam suasana seperti ini, ketika batas-batas norma tak lagi disadari, maka bisa terjadi berbagai pola tindakan yang mengancam solidaritas.

\section{Agama Menurut Emile Durkheim}

Agama secara sosiologis disebut suatu jenis sistem sosial, menjelaskan bahwa agama adalah suatu fenomena sosial, suatu peristiwa kemasyarakatan,

${ }^{8}$ Bryan S.Turner, Agama dan Teori Sosial (Rangka-Pikir Sosiologi Dalam Membaca Eksistensi Tuhan Di Antara Gelegar Idiologi Kontemporer), alih Bahasa, Inyiak Ridwan Muzir, (Yogyakarta; IRCiSoD, 2003), hlm.88-89 
Al-Fikra: Jurnal Ilmiah Keislaman, Vol. 5, No. 1, Januari-Juni 2006

suatu sistem sosial dapat dianalisis, karena terdiri atas suatu kompleks kaidah dan peraturan yang dibuat saling berkaitan dan terarahkan kepada tujuan tertentu. Manusia mendayagunakan kekuatan-kekuatan non-empiris untuk kepentingannya sendiri dan masyarakat sekitarnya. Yang dimaksud dengan kepentingan (keselamatan) ialah keselamatan di dalam dunia sekarang ini dan keselamatan di "dunia lain" yang dimasuki manusia sesudah kematian.

Baiklah kiranya dapat ditekankan bahwa pemahaman sosiologi atas agama tidak ditamba dari "pewahyuan" yang datang dari dunia luar, tetapi diangkat dari eksperiensi, atau pengalaman konkret sekitar agama yang dikumpulkan dari sana-sini. Dengan kata singkat, defenisi agama menurut sosiologi adalah defenisi yang empiris. Sosiologi tidak pernah memberikan defenisi agama yang evaluatif (menilai). Ia 'angkat tangan' mengenai hakekat agama, baik atau buruknya agama yang tengah diamatinya. Dari pengamatan ini ia hanya sanggup memberikan defenisi yang deskriftif, yang mengungkapkan apa yang dimengerti atau dialami pemeluk-pemeluknya.

Menurut Durkheim agama adalah;

a religion is a unfied system of beliefs and practices relative to sacred things, that is to say, things set apart and forbidden - beliefs and practices which unite into one single moral community called a church, all those who adhere to them ${ }^{9}$ (suatu agama adalah suatu system kepercayaan yang disatukan oleh praktek-praktek yang bertalian dengan hal-hal yang suci, yakni hal-hal yang dibolehkan dan dilarang - kepercayaan dan praktek-praktek yang mempersatukan suatu komunitas moral yang disebut Gereja, semua mereka yang terpaut satu sama lain).

Jadi agama merupakan suatu proyeksi pengalaman masyarakat. Kekudusan dan masyarakat merupakan hal yang satu dan sama. Agama adalah sarana ungkapan simbolis kehidupan kolektif total.. Durkheim mengidentifikasikan agama dengan masyarakat, semakin kuat dan erat ikatan sosial suatu masyarakat, semakin dalamlah perasaan religius dan perasaan mengenai hal yang kudus yang menyertai setiap menifestasi kolektif.

Yang terpenting dari segala yang sakral (agama) itu sendiri adalah kemampuannya untuk membangkitkan perasaan kagum bagi para pemeluknya dan karena itu ia memiliki kekuatan memaksa (dalam mengatur) tingkah laku manusia serta kekuatan untuk mengukuhkan nilai-nilai moral kelompok pemeluk. ${ }^{10}$ Masyarakat tentu akan patuh pada sesuatu yang dikaguminya, apalagi yang dikagumi itu memiliki kekuatan yang luar biasa.

Agama pada mulanya muncul karena adanya suatu geteran, suatu emosi yang ditimbulkan dalam jiwa manusia sebagai akibat dari pengaruh rasa kesatuan sebagai sesama warga masyarakat. Teori yang disebut "Teori

9 Emile Durkheim, The Elementary Form Of The Religious Life (New York: Free Press, 1992), hlm.80

10 Elizabet K.Nottingham, Agama dan Masyarakat, Suatu Pengantar Sosiologin Agama, Alih bahasa, Abdul Muis Naharong, (Jakarta; PT. Raja Grafindo Persada, 1997), hlm. 40 
sentimen kemasyarakatan". Emile Durkheim menguraikan dalam bukunya Les Formes Elementaires de Lavia Religiuse, diterjemahkan ke dalam bahasa Inggris oleh Karen E.Fields; The Elementary Form of The Religious Life (1965). Dalam bukunya itu, Durkheim mengemukakan teorinya tentang dasar-dasar agama yang sama sekali berbeda dengan teori yang pernah dikembangkan oleh para ilmuwan sebelumnya.

Teori itu berpusat pada pengertian dasar berikut;

a. Bahwa untuk pertama kalinya, aktivitas religi yang ada pada manusia bukan karena pada alam pikirannya terdapat bayang-bayangan abstrak tentang jiwa atau roh -suatu kekuatan yang menyebabkan hidup dan gerak di dalam alam- tetapi, karena suatu getaran jiwa, atau emosi keagamaan, yang timbul dalam alam jiwa manusia dahulu, kerana pengaruh sentimen kemasyarakatan.

b. Bahwa sentimen kemasyarakatan dalam batin manusia dahulu berupa suatu kompleksitas perasaan yang mengandung rasa terikat, bakti, cinta dan perasaan lainnya terhadap masyarakat di mana ia hidup.

c. Bahwa sentimen kemasyarakatan yang menyebabkan tibulnya emosi keagamaan dan merupakn pangkal dari segala kelakuan keagamaan manusia itu, tidak selalu berkobar-kobar dalam batinnya. Apabila tidak dipelihara, maka sentimen kemasyarakatan itu menjadi lemah dan laten, sehingga perlu dikobarkan sentimen kemasyarakatan dengan mengadakan suatu kontraksi masyarakat, artinya dengan mengumpulkan seluruh masyarakat dalam pertemuan-pertemuan raksasa.

d. Emosi kegamaan yang timbul karena rasa sentimen kemasyarakatan membutuhkan suatu objek tujuan. Sifat yang menyebabkan sesuatu itu menjadi objek dari emosi keagamaan bukan karena sifat luar biasanya, anehnya, megahnya, atau ajaibnya, melainkan tekanan anggapan umum masyarakat. Objek itu ada karena terjadinya satu peristiwa secara kebetulan di dalam sejarah kehidupan suatu masyarakat masa lampau menarik perhatian orang banyak di dalam masyarakat tersebut. Objek yang menjadi tujuan emosi keagamaan juga objek yang bersifat keramat. Maka objek lain yang tidak mendapat nilai keagamaan (tirual value) dipandang sebagai objek yang tidak keramat.

e. Objek keramat sebenarnya merupakan suatu lambang masyarakat. Pada suku-suku bangsa asli Australia, misalnya, objek keramat dan pusat tujuan dari sentimen kemasyarakatan, sering berupa binatang dan tumbuhtumbuhan. Objek keramat seperti ini disebut Totem. Totem adalah mengkonkretkan prinsip totem di belakangnya. Dan prinsip totem itu adalah suatu kelompok di dalam masyarakat berupa clan (suku) atau lainnya. ${ }^{11}$

Jadi agama menurut Durkheim lahir dari masyarakat itu sendiri tanpa unsur pewahyuan dari sang pencipta. Agama merupakan penjelmahan dari

11 Emile Durkheim, The Elementary ..., hlm.599-604. Lihat juga, Dadang Kahmad, Sosiologi Agama hlm.30 
Al-Fikra: Jurnal Ilmiah Keislaman, Vol. 5, No. 1, Januari-Juni 2006

masyarakat itu sendiri. Karena agamalah masyarakat itu dapat berlangsung. Ketika agama hilang maka masyarakatpun akan hilang. Oleh sebab itu agar keberadaan masyarakat terus bisa eksis, maka orang akan mencari alternatif lain yang bisa menggantikan peranan agama.

\section{Hubungan Agama Dengan Solidaritas Sosial}

Emile Durkheim, menyimpulkan bahwa tujuan utama agama dalam masyarakat primitif adalah membantu orang berhubungan bukan dengan tuhannya, melainkan dengan sesamanya. Ritual-ritual religius membantu orang untuk mengembangkan rasa solidaritas, rasa sepaguyuban (sense of community), rasa berkelompok (group feeling). Misalnya mereka bersama-sama ambil bagian dalam pesta perkawinan, mengantarkan sesajian, pesta kelahiran dan kematian, dan bersama-sama merayakan musim tanam dan panen. Hal itu dapat mempersatukan kelompok dengan cara kontraksi religius.

Durkheim $\sim$ yang telaahannya terfokus pada unsur-unsur sosial yang menghasilkan solidaritas melihat agama sebagai faktor esensial bagi identitas dan integrasi masyarakat. Menurut Durkheim "Agama merupakan suatu sistem interpretasi diri kolektif . Dengan kata lain, agama adalah sistem simbol di mana masyarakat bisa menjadi sadar akan dirinya; sistem simbol yang ada merupakan penjelmahan dari masyarakat itu sendiri, ia adalah cara berpikir tentang eksistensi kolektif." Agama tidak lain adalah proyeksi masyarakat sendiri dalam kesadaran manusia. Selama masyarakat masih berlangsung, agamapun akan tetap lestari. Masyarakat bagaimanapun akan tetap menghasilkan simbol-simbol pengertian diri kolektifnya, dan dengan demikian menciptakan agama.

Durkheim menjelaskan bahwa agama dapat menumbuhkan rasa solidaritas (mekanis) di antara pemeluknya. Durkheim meneliti masyarakat suku Arunta, yaitu salah satu suku primitif di Australia. Durkheim berkesimpulan bahwa karena agamalah masyarakat saling berinteraksi dengan akrab dan intim, mereka sama-sama melakukan do'a, perayaan ibadah (liturgis), sesajian dan lainnya. Akhirnya mereka saling akrab, simpati dan setia karena mereka sama-sama memiliki satu tujuan dan cita-cita. Semua benda dan makhluk yang oleh manusia diberi sifat sacral pada dasarnya hanyalah lambinglambang dari kelompok manusia itu sendiri, dan menempatkan masyarakat sebagai tujuan akhir upacara peribatan manusia. ${ }^{12}$

Pada awalnya masyarakat pemeluk agama secara bersama melakukan upacara keagamaan, seperti memberikan sesajian, menguburkan jenazah, doa bersama dan lainnya. Kemudian acara-acara seperti itu membengkitkan kegembiraan bersama (kolektif), kemudian selanjutnya menimbulkan sentimen

${ }^{12}$ Ibid., hlm.206 
Al-Fikra: Jurnal Ilmiah Keislaman, Vol. 5, No. 1, Januari-Juni 2006

bersama, simpati sesama, membangkitkan rasa cinta, suka kepada orang sekelilingnya, kemudian pada akhirnya menimbulkan keyakinan bersama. ${ }^{13}$

Upacara kolektif $=>$ kegembiraan kolektif $=>$ sentimen kolektif $=>$ keyakinan kolektif

Dari hasil pengamatan Durkheim pada masyarakat Aborijin, khususnya suku Arunta, Australia. Beliau melihat bahwa masing-masing anggota masyarakat saling mengidentifikasikan dirinya dengan yang lain. Identifikasi muncul karena memang Durkheim beranggapan bahwa masyarakat dari sukusuku Aborigin itu bersifat utuh dan murni. Tetapi identifikasi ini menjadi buyar, ketika masyarakat telah mengalami pluralitas, akibat urbanisasi dan modernisasi. Identifikasi ini menjadi terancam karena merosotnya solidaritas mekanis dan munculnya solidaritas organis. Dengan buyarnya identifikasi, maka tentu saja agamapun kehilangan fungsinya.

Jadi menurut Durkheim, pada masyarakat primitif yang bercirikan solidaritas mekanik maka peranan agama sangat penting, agama sebagai pemersatu. Kemudian pada masyarakat kota (modern) yang bercirikan solidaritas organik fungsi agama berkurang, bahkan bisa hilang, karena meningkatnya rasionalisasi Di sini peranan agama kehilangan kemampuannya sebagai pengikat solidaritas sosial. Pada situasi seperti inilah Emile mengkwatirkan masa depan agama, agama digantikan oleh rasio. Jika suatu masa agama tidak dipakai lagi oleh masyarakat, harus ada alternatif lain, moral lain yang bisa menggantikan fungsi agama sebagai pemersatu, kalau tidak ada maka masyarakat akan ambruk dengan sendirinya bersamaan dengan hilangnya agama itu.

Walaupun didasari oleh analisis yang berbeda, namun pandangan Durkheim di atas juga didukung oleh para sosiolog seperti, Max Weber dan Ferdinand Tonnies, dan lain-lain. Mereka juga berpendapat bahwa agama mempunyai dimensi sosiologis, seperti menguatkan persaudaraan (solidaritas), motivasi kerja dan lain-lain. Weber menjelaskan bahwa agama sebagai sumber struktur masyarakat, agama sebagai faktor perubahan sosial, bahkan agama dapat meningkatkan etos kerja, seperti yang ia jelaskan dalam bukunya The Protestant Etic and The Spirit Of Capitalism, tentang etos kerja Kristen Protestan (yang diilhami oleh Calvinisme-Asketisisme) menjadi cikal bakal timbulnya kapitalisme Eropa. Lain halnya dengan Karl Marx, ia menganggap bahwa disamping agama sebagai pemersatu (yang menjadi sasaran tesisnya "candu masyarakat", juga sebagai kekuatan yang memisahkan. ${ }^{14}$ Para sosiolog ataupun para filosof seperti Nitzse, Sigmund Freud, Lenin dan lain-lain (apalagi mereka yang hidup zaman Renaisan) juga mengkwatirkan masa depan agama, agama kehilangan fungsi di tengah masyarakat, agama digantikan oleh

13 Bryan S.Turner, Sosiologi Islam ..., hlm.90

14 Stephen K.Sanderson, Makro Sosiologi, (sebuah pendekatan Terhadap Realitas sosial), Alih bahasa, Farid wajidi, (Jakarta; PT.Raja Grafindo Persada, 2000), hlm. 555. 
kekuatan rasio manusia. Sekali lagi, walaupun analisisnya berbeda dengan analisis Durkheim.

Dari urain di atas jelaslah bahwa agama merupakan media interaksi umat yang efektif, yang pada akhirnya melahirkan solidaritas, khususnya bagi umat satu agama tertentu. Memang dari pengalaman sejarah tidak bisa dipungkiri bahwa agama telah memberikan sumbangan yang sangat besar dalam menciptakan suatu ikatan bersama, baik diantara anggota-anggota beberapa masyarakat maupun bagi umat.

Namun pertanyaan yang muncul selanjutnya adalah, apakah agama Islam juga menguatkan solidaritas umat muslim?

Agama yang didefenisikan oleh Durkheim tentu sangat berbeda dengan Agama Islam. Agama yang dimaksud oleh Durkheim adalah sistem sosial, budaya manusia, suatu proyeksi pengalaman masyarakat. Kekudusan dan masyarakat merupakan hal yang satu dan sama. Agama adalah sarana ungkapan simbolis kehidupan kolektif total. Agama dipandang sebagai sistem kepercayaan yang diwujudkan dalam prilaku sosial tertentu. Ia berkaitan dengan pengalaman manusia, baik sebagai individu maupun kelompok. Sehingga, setiap perilaku yang diperankannya akan terkait dengan system keyakinan dari ajaran agama yang dianutnya. Perilaku individu dan sosial digerakkan oleh kekuatan dari dalam yang didasarkan pada nilai-nilai ajaran agama yang menginternalisasi sebelumnya. Disisi lain, Islam adalah agama yang diturunkan melalui wahyu Tuhan kepada nabinya Muhammad, bukan dihasilkan dari pengalaman manusia, bukan hasil pemikiran dan karya manusia (budaya).

Terlepas dari perbedaan di atas, namun yang menjadi fokus disini bukan kebenaran suatu agama tetapi adalah, apakah masyarakat muslim juga memiliki solidaritas yang kuat, dan apakah solidaritas itu terjadi karena pengaruh agama yang mereka anut, yang telah menginternalisasi dalam dirinya.

Menurut Soerjono Soekanto, suatu masyarakat akan kuat solidaritasnya apabila ada satu faktor yang dimiliki bersama. Faktor tadi merupakan nasib yang sama, kepentingan yang sama, idiologi dan agama yang sama. ${ }^{15}$

Menurut Charles Horton Cooley (1864-1929), agar terjadi solidaritas yang kuat dalam masyarakat, individu-individu anggota masyarakat mau tak mau secara fisik harus saling mengenali. Saling berbicara dan saling melihat merupakan saluran utama untuk pertukaran fikiran, cita-cita maupun perasaan. Semakin sering anggota masyarakat itu berinteraksi maka semakin kuat pula keintiman dan rasa solidaritasnya, karena masing-masing anggota semakin dalam memahami perasaan orang lain dan begitu juga sebaliknya. ${ }^{16}$

Menurut Prof. Jalaluddin, bahwa penganut agama yang sama secara psikologis akan merasa memiliki kesamaan dalam satu kesatuan; iman dan kepercayaan. Rasa kesatuan ini akan membina rasa solidaritas dalam kelompok,

\footnotetext{
15 Soerjono Soekanto, Sosiologi,(Jakarta: PT.Raja Grafindo Persada,2001), hlm.135

16 Selo Soemarjan, Setangkai Bunga Sosiologi,(Jakarta: Yayasan Fekon UI,1964), hlm.401
} 
bahkan kadang-kadang dapat membina persaudaraan yang kokoh, bahkan juga dapat mengalahkan rasa kebangsaan. ${ }^{17}$

Bahkan Ibnu Khaldun mengatakan bahwa solidaritas ('ashobiyah) yang didasari oleh akidah/agama sama bahkan bisa lebih kuat dari solidaritas yang didasari oleh hubungan darah atau keluarga (nasab). Dari pengamatan Khaldun terhadap berdiri dan runtuhnya suatu kerajaan/dinasti, bahwa apabila orangorang yang mendirikan suatu kerajaan/dinasti terdiri dari orang-orang yang satu agama maka kerajaan/dinasti itu akan berlangsung kuat. ${ }^{18}$

Dari pendapat para ahli di atas jelaslah bahwa secara psikologis orang yang sering berinteraksi, bekerja sama, senasip sepenanggungan, memiliki tujuan dan keyakinan yang sama akan terjadi keintiman, solidaritas yang kuat diantara sesama mereka.

Ajaran Islam banyak sekali perintah-perintah dan anjuran-anjuran yang menyuruh umatnya berbuat baik kepada orang lain, memperbaiki hubungan dengan orang lain, menyayangi dan mencintai orang lain, dilarang memutuskan solidaritas, bahkan Islam mengajarkan umatnya agar mencintai orang lain seperti mencintai diri sendiri. Disamping perintah-perintah itu, ajaran Islam juga menyuruh umatnya untuk melaksanakan ritual atau ibadah-ibadah tertentu sebagai bukti pengabdian kepada Allah.. Diantara ritual-ritual itu berhubungan dengan tindakan sosial kemasyarakatan (liturgis).

Orang-orang muslim sering melakukan ritual keagamaan secara bersamasama, seperti melakukan shalat secara berjamaah, melakukan perayaan bersama-sama, berkumpul di Mekah untuk melaksanakan ibadah haji, melaksakan ibadah korban pada hari raya haji, bersama-sama pergi berziarah ketempat orang meninggal dunia, memperingati hari-hari besar Islam seperti Maulid Nabi dan Isra' mi'raj, bermusyawarah dan banyak lagi ritual keagaman yang berhubungan dengan tindakan sosial.

Semua perintah ritual-ritual di atas apabila dilakukan berulang-ulang, akan dimenjadikan umat muslim sering berkumpul, saling berinteraksi satu sama lain, saling memahami. Dengan seringnya berkumpul melakukan ritual keagamaan itu akan menimbulkan getaran-getaran jiwa diantara sesama anggota kelompok ibadah, bergembira dan sedih bersama, mempunyai tujuan dan cita-cita yang sama, keyakinan yang sama, dan merasa senasip sepenanggungan. Kemudian akhirnya akan mendatangkan sentimen perasaan, rasa simpati, identifikasi, rasa memiliki, rasa cinta diantara sesama.

Dengan demikian ajaran Islam juga berdampak sosiologis yaitu dapat membuat umatnya menjadi masyarakat yang memiliki solidaritas yang kuat dikarnakan seringnya menjalankan perayaan dan ritual-ritual keagamaan. Inilah

${ }^{17}$ Jalaluddin, Fsikologi Agama, (Jakarta: PT.Raja Grafindo Persada,2002), hlm.247. Lihat juga; Ishomuddin, Sosiologi Agama, hlm.55

18 Ibnu Khaldun, Muqaddimah, (Jakarta: Pustaka Firdaus, 2000),hlm. 152 
yang dikatakan oleh para pakar di atas, bahwa penganut agama yang sama secara psikologis akan merasa memiliki kesamaan dalam satu kesatuan; iman dan kepercayaan. Rasa kesatuan ini akan membina rasa solidaritas dalam kelompok, bahkan kadang-kadang dapat membina persaudaraan yang kokoh, bahkan juga dapat mengalahkan rasa kebangsaan.

Hal tersebut juga dapat kita lihat dalam sejarah umat Islam. Sebelum Islam datang, bangsa Arab terkenal dengan sebutan sebagai "bangsa-bangsa yang terpecah-pecah dalam berbagai kabilah dan suku". Mereka sering terlibat konflik dan peperangan antar suku dan antar keluarga, sehingga bangsa Arab pada waktu itu disebut masyarakat jahiliyah, yang berarti masyarakat tidak beradab. Tetapi setelah Islam datang dan berkembang di daerah itu, mereka menjelma menjadi bangsa yang bersatu dan mampu memperlihatkan kekuatannya sehingga bangsa-bangsa lain bisa ditaklukannya.

Kemudian kalau kita melihat negara kita, ketika negara Indonesia dijajah oleh bangsa lain, para pejuang kemerdekaan menggunakan isu kesamaan agama/akidah untuk menyatukan langkah perjuangan dalam mengusir kaum penjajah yang diidentifikasi sebagai pemeluk agama yang berbeda dengan kebanyakan masyarakat Indonesia. Isu kesamaan agama/akidah telah berhasil memberikan semangat persatuan, solidaritas yang luar biasa, khususnya bagi masyarakat muslim, sehingga dengan bekal itulah para penjajah berhasil dihalau dari tanah air.

Dua bukti sejarah di atas memperlihatkan kepada kita tetntang salah satu fenomena masa lalu disamping banyak sejarah umat manusia lainnya, bahwa banyak masyarakat yang tadinya terpecah belah bisa bersatu dan berintegrasi karena memeluk agama yang sama. Agama yang dipeluk oleh anggota masyarakat tertentu bisa membangkitkan rasa solidaritas dan kohesifitas sosial yang kuat. Agama bisa menjadi perekat persatuan dan kesatuan suatu bangsa, suatu masyarakat desa, dan atau komunitas tertentu.

\section{Kesimpulan}

Dari urain Durkheim jelaslah bahwa Agama merupakan suatu proyeksi pengalaman masyarakat. Kekudusan dan masyarakat merupakan hal yang satu dan sama. Agama adalah sarana ungkapan simbolis kehidupan kolektif total. Durkheim mengidentifikasikan agama dengan masyarakat, semakin kuat dan erat ikatan sosial suatu masyarakat, semakin dalamlah perasaan religius dan perasaan mengenai hal yang kudus yang menyertai setiap menifestasi kolektif.

Yang terpenting dari segala yang sakral (agama) itu sendiri adalah kemampuannya untuk membangkitkan perasaan kagum bagi para pemeluknya dan karena itu ia memiliki kekuatan memaksa (dalam mengatur) tingkah laku manusia serta kekuatan untuk mengukuhkan nilai-nilai moral kelompok pemeluk. Masyarakat akan patuh pada sesuatu yang dikaguminya, apalagi yang dikagumi itu memiliki kekuatan yang luar biasa. Agama pada mulanya muncul karena adanya suatu geteran, suatu emosi yang ditimbulkan dalam jiwa 
Al-Fikra: Jurnal Ilmiah Keislaman, Vol. 5, No. 1, Januari-Juni 2006

manusia sebagai akibat dari pengaruh rasa solidaritas sebagai sesama warga masyarakat.

Agama yang didefenisikan oleh Durkheim sangat berbeda dengan Agama Islam. Agama yang dimaksud oleh Durkheim adalah sistem sosial, budaya manusia, suatu proyeksi pengalaman masyarakat. Kekudusan dan masyarakat merupakan hal yang satu dan sama. Agama adalah sarana ungkapan simbolis kehidupan kolektif total. Agama dipandang sebagai sistem kepercayaan yang diwujudkan dalam prilaku sosial tertentu. Ia berkaitan dengan pengalaman manusia, baik sebagai individu maupun kelompok. Sehingga, setiap perilaku yang diperankannya akan terkait dengan system keyakinan dari ajaran agama yang dianutnya. Perilaku individu dan sosial digerakkan oleh kekuatan dari dalam yang didasarkan pada nilai-nilai ajaran agama yang menginternalisasi sebelumnya. Disisi lain, Islam adalah agama yang diturunkan melalui wahyu Tuhan kepada nabinya Muhammad, bukan dihasilkan dari pengalaman manusia, bukan hasil pemikiran dan karya manusia atau budaya manusia.

Ajaran Islam banyak sekali perintah-perintah dan anjuran-anjuran yang menyuruh umatnya berbuat baik kepada orang lain, memperbaiki hubungan dengan orang lain, menyayangi dan mencintai orang lain, dilarang memutuskan solidaritas, bahkan Islam mengajarkan umatnya agar mencintai orang lain seperti mencintai diri sendiri. Disamping perintah-perintah itu, ajaran Islam juga menyuruh umatnya untuk melaksanakan ritual atau ibadah-ibadah tertentu sebagai bukti pengabdian kepada Allah.. Diantara ritual-ritual itu berhubungan dengan tindakan sosial kemasyarakatan.

Semua perintah ritual-ritual di atas apabila dilakukan berulang-ulang, akan dimenjadikan umat muslim sering berkumpul, saling berinteraksi satu sama lain, saling memahami. Dengan seringnya berkumpul melakukan ritual keagamaan itu akan menimbulkan getaran-getaran jiwa diantara sesama anggota kelompok ibadah, bergembira dan sedih bersama, mempunyai tujuan dan cita-cita yang sama, keyakinan yang sama, dan merasa senasip sepenanggungan. Kemudian akhirnya akan mendatangkan sentimen perasaan, rasa simpati, identifikasi, rasa memiliki, rasa cinta diantara sesama. Dengan demikian ajaran Islam juga berdampak sosiologis yaitu dapat membuat umatnya menjadi masyarakat yang memiliki solidaritas yang kuat dikarnakan seringnya menjalankan perayaan dan ritual-ritual keagamaan.

\section{Bibliografi}

Abdullah, Taufik dan A.C.Vander Leeden (Penyunting), Durkheim dan Pengantar Sosiologi Moralitas, (Jakarta: Yayasan Obor indonesia, 1986)

Durkheim, Emile, The Elementary Form Of The Religious Life (New York: Free Press,1992)

Ibnu Khaldun, Muqaddimah, (Jakarta: Pustaka Firdaus, 2000)

Jalaluddin, Fsikologi Agama, (Jakarta: PT.Raja Grafindo Persada, 2002) 
Al-Fikra: Jurnal Ilmiah Keislaman, Vol. 5, No. 1, Januari-Juni 2006

Kernermen, Lionel, Password, (Bekasi Timur; PT.Kesaint blanc Indah Corp, 1999)

Koentjaraningrat, Ilmu Antropologi, (Jakarta : PT.Rineka Cipta, 1990)

Nottingham, Elizabet K., Agama dan Masyarakat, Suatu Pengantar Sosiologin Agama, Alih bahasa, Abdul Muis Naharong, (Jakarta; PT. Raja Grafindo Persada, 1997)

Peter Salim, Yeni Salim, Kamus Bahasa Indonesia, Jakarta; Modern English Press, 1991)

Sanderson, Stephen K., Makro Sosiologi, (sebuah pendekatan Terhadap Realitas sosial), Alih bahasa, Farid wajidi, (Jakarta; PT.Raja Grafindo Persada, 2000)

Soemarjan, Selo, Setangkai Bunga Sosiologi,(Jakarta: Yayasan Fekon UI,1964)

Soekanto, Soerjono, Kamus Sosiologi, (Jakarta; PT.Raja Grafindo Persada, 1985) , Sosiologi,(Jakarta: PT.Raja Grafindo Persada,2001)

Suparlan, Parsudi, Orang Sakai Di Riau, Masyarakat Terasing Dalam Masyarakat Indonesia, (Jakarta: Yayasan Obor Indonesia, 1995)

Turner, Bryan S., Agama dan Teori Sosial Rangka-Pikir Sosiologi Dalam Membaca Eksistensi Tuban Di Antara Gelegar Idiologi Kontemporer), alih Bahasa, Inyiak Ridwan Muzir, (Yogyakarta; IRCiSoD, 2003)

Sosiologi Islam, Suatu Telaah analitis Atas Tesa Sosiologi Weber, alih bahasa, G.A.Ticoalu, (Jakarta: PT. Raja Grafindo Persada, 1994) 